\title{
Peran Sensitivitas Harga dalam Memoderasi Minat Pembelian
}

\author{
Kristian Suhartadi Widi Nugraha ${ }^{1}$, Bachtiar Maliki \\ ${ }^{1,2}$ Fakultas Ekonomi dan Bisnis, Universitas Jember \\ Jl. Kalimantan No. 37, Jember, Indonesia \\ e-mail: ${ }^{1}$ kristian.feb@unej.ac.id, ${ }^{2}$ bachtiar.bacht@gmail.com
}

Informasi Artikel Diterima: 12-01-2021 Direvisi: 24-01-2021 $\quad$ Disetujui: 02-02-2021

\begin{abstract}
Abstrak
Penelitian ini bertujuan untuk mengetahui bagaimana peran sensitivitas harga sebagai moderasi dari kualitas produk, periklanan dan perceived risk terhadap minat pembelian. Sampel diambil dengan teknik purposive sampling dengan mengambil data dari 120 responden melalui kuesioner. Penelitian dilakukan menggunakan pendekatan penelitian eksplanatori dengan jenis penelitian kuantitatif. Analisis data menggunakan SEM-PLS menggunakan smartpls 3.0. Hasil penelitian menunjukkan bahwa kualitas produk berpengaruh signifikan terhadap minat pembelian, periklanan berpengaruh signifikan terhadap minat pembelian dan perceived risk berpengaruh signifikan terhadap minat pembelian, namun sensitivitas harga hanya dapat memoderasi periklanan terhadap minat pembelian. Sedangkan pada kualitas produk dan perceived risk, sensitivitas harga tidak memoderasi.
\end{abstract}

Kata Kunci: kualitas produk, periklanan, perceived risk, sensitivitas harga,minat pembelian

\begin{abstract}
This study aims to determine the role of price sensitivity as a moderation of product quality, advertising, and perceived risk on purchase interest. The sample was taken using the purposive sampling technique by taking data from 120 respondents through a questionnaire. The research was conducted using an explanatory research approach with quantitative research types-data analysis using SEM-PLS using smartpls 3.0. The results showed that product quality had a significant effect on purchase intention. Advertising has a significant impact on purchase intention, and perceived risk significantly affected purchase intention. Still, price sensitivity could only moderate advertising on purchase intention. Whereas in product quality and perceived risk, price sensitivity did not moderate.
\end{abstract}

Keywords: product quality, advertising, perceived risk, price sensitivity, purchase interest

\section{Pendahuluan}

Bentuk e-commerce yang banyak diminati di internet saat ini adalah online marketplace atau online shop (Dabrynin \& Zhang, 2019). Terbukanya peluang pasar pada bisnis marketplace tentu menguntungkan bagi individu atau UKM, karena mereka dapat menjual produknya secara online. Marketplace pada dasarnya adalah sarana untuk memudahkan akses dan interaksi antara penyedia dengan konsumen (Arbaini et al., 2020). Selain itu, berbagai layanan dan kemudahan yang diberikan kepada konsumen untuk memahami produk apa yang akan dibeli, bagaimana spesifikasinya dan review yang diberikan konsumen lain bahkan dilengkapi dengan video ulasan dan rating yang diberikan secara online (Arbaini et al., 2020; Belarmino \& Koh, 2018; Primanto et al., 2018). Menurut laporan survey APJII (Asosiasi Penyelenggara Jasa Internet Indonesia) tahun 2020 (Q2) pengguna internet di Indonesia sebanyak 196,71 juta jiwa dari 266,91 juta jiwa penduduk
Indonesia dengan growth atau pertumbuhan user sebanyak $8,9 \%$ atau 25,5 juta jiwa.

Aktifnya pengguna internet di Indonesia dan jumlah penduduk yang besar menjadi salah satu peluang dalam perkembangan marketplace di Indonesia. Merujuk data yang dirilis iprice.co.id mengenai peta persaingan e-commerce Q3 tahun 2020 menunjukkan walaupun Indonesia dan belahan dunia lain dihantam pandemic virus Covid-19 yang merusak stabilitas ekonomi selama ini namun bisnis marketplace dapat bertahan dan terus menunjukkan kinerja positif walaupun lebih lambat disbanding periode yang sama tahun 2019. Aktivitas belanja online yang berarti tidak ada kontak langsung, menjadikan bisnis online selama pandemi semakin lama mengalami kenaikan transaksi. Rilis katadata.com mengenai rata-rata kunjungan website e-commerce bulanan pada kuartal II tahun 2020 menunjukkan bahwa Shopee masih menjadi jawara dengan rata-rata kunjungan 93,4 juta, disusul Tokopedia dengan rata-rata kunjungan 86,1 juta dan 
ditempat ketiga Bukalapak dengan jumlah rata-rata kunjungan 35,5 juta.

Sebagai salah satu pioner dan pemimpin marketplace di Indonesia, Tokopedia melayani aneka macam produk yang dijual termasuk produk clothing. Walaupun selama pandemi tahun 2020, produk terlaris adalah mengenai makanan, minuman dan suplemen kesehatan serta hal-hal yang berkaitan dengan olah raga namun produk clothing tetap diburu oleh konsumen sebagai salah satu kebutuhan sandang yang harus dipenuhi. Produk clothing atau pakaian sebagai kebutuhan primer manusia yang tentunya dibutuhkan oleh semua kalangan berpotensi untuk lebih unggul dibanding produk mobile \& electronics yang merupakan kebutuhan tersier. Hal tersebut diperkuat dengan data terkait kategori barang yang paling banyak dibeli konsumen pada Tahun 2020 yang menempatkan produk clothing di urutan keempat. Dengan meninjau peluang pasar pada produk clothing, maka dapat diketahui bahwa meningkatkan jumlah penjualan produk clothing dengan cara merangsang minat beli pelanggan dapat dijadikan salah satu opsi oleh Tokopedia untuk bertahan dan menjaga keberlangsungan dalam ketatnya persaingan e-commerce.

Minat pembelian merupakan komponen perilaku kognitif konsumen yang menggambarkan niat khusus untuk membeli sesuatu (Dabrynin \& Zhang, 2019). Manajemen umumnya menggunakan minat pembelian sebagai wahana untuk memprediksi penjualan serta mengembangkan strategi promosi. Minat pembelian online berkaitan erat dengan perilaku konsumen (Dabrynin \& Zhang, 2019; Singhal et al., 2019), persepsi dan sikap yang digunakan untuk memprediksi proses pembelian (Rosillo-Díaz et al., 2019; Tham et al., 2019). Tjiptono \& Diana (2020) menegaskan bahwa dalam proses keputusan pembelian banyak factor yang perlu diperhatikan seperti factor personal, factor situasional, factor fisik dan sosial serta factor disposisional konsumen. Berdasarkan hal tersebut dapat diketahui bahwa merangsang minat beli pelanggan merupakan salah satu solusi yang perlu dilakukan Tokopedia untuk mampu bertahan dalam ketatnya persaingan e-commerce. Peluang pasar dan jumlah transaksi pada produk clothing menunjukkan bahwa Tokopedia perlu merangsang minat beli pelanggan terhadap produk clothing.

Beberapa pakar menegaskan bahwa minat pembelian dipengaruhi oleh kualitas produk (Flanagin et al., 2014; Mirabi et al., 2015), periklanan (Mandliya et al., 2020; Martins et al., 2019) dan perceived risk (Pelaez et al., 2017; Tham et al., 2019). Schiffman \& Wisenblit (2015) menegaskan ketika kualitas produk sesuai dengan ekspektasi pelanggan maka kemungkinan besar pelanggan berminat untuk melakukan pembelian. Kualitas produk merupakan keharusan (Yan et al., 2019), namun perlu diingat bahwa kualitas umumnya berkaitan dengan harga produk tersebut.
Pemahaman di benak konsumen umumnya adalah kualitas yang baik biasanya berdampak pada harga yang mahal sehingga produsen membuat segmen produk yang beraneka ragam untuk melayani konsumen.

Kualitas produk adalah keseluruhan fitur dan karakteristik suatu barang atau jasa yang bertanggung jawab untuk memuaskan kebutuhan yang tersurat maupun tersirat (Kotler \& Keller, 2016). Kualitas produk dapat dipahami sebagai persepsi dan kesadaran konsumen (Saleem et al., 2015), artinya tidak semua konsumen membutuhkan produk yang berkualitas selama nyaman dipakai dan sesuai dengan segmentasi dan group reference konsumen (Sasmita \& Mohd Suki, 2015). Secara mendasar sebenarnya konsumen memahami bahwa kualitas akan membawa konsekuensi tertentu namun beberapa peneliti juga menemukan bahwa dalam beberapa kasus dan beberapa produk, konsumen cenderung abai terhadap kualitas suatu produk. Pengelolaan kualitas produk pada online marketplace biasanya berupa policy atau kebijakan yang mengatur hak dan kewajiban penjual maupun pembeli. Berdasarkan hal tersebut Tokopedia harus mampu memberlakukan policy yang mampu mengontrol kualitas produk clothing di situs mereka, sehingga produk clothing yang ada di situs mereka adalah produk clothing yang terjamin kualitasnya.

Kualitas produk juga cenderung dikaitkan dengan niat membeli yang lebih tinggi, konsumen cenderung membeli produk yang mereka nilai kualitasnya lebih tinggi. Secara sederhana, kualitas produk yang dirasakan telah ditemukan berkorelasi positif dengan pembelian niat dalam transaksi komersial (Flanagin et al., 2014). Niat membeli mungkin tidak hanya didasarkan pada kenyamanan harga, tetapi juga dapat mencerminkan evaluasi kualitas produk (Calvo-Porral \& Lévy-Mangin, 2017), selain itu persepsi harga dan sensitivitas harga juga berperan dalam niat membeli dari sisi nilai yang dirasakan (Wang \& Chen, 2016).

Selain memiliki produk yang berkualitas, Tokopedia juga harus mempublikasikan produknya. Publikasi produk atau pengenalan produk kepada masyarakat luas disebut dengan periklanan. Periklanan adalah segala bentuk presentasi non personal dan promosi ide-ide, barang, atau jasa yang didanai oleh sponsor (Kotler \& Keller, 2016). Sedangkan menurut Mandliya et al (2020), periklanan adalah jenis komunikasi pemasaran yang digunakan pemasar untuk menjangkau konsumen dan menyampaikan pesannya. Iklan selain bertujuan untuk mengenalkan produk kepada masyarakat juga memiliki fungsi reminder, yaitu untuk merangsang pelanggan agar melakukan pembelian (Gong et al., 2019). Gagasan tersebut diperkuat dengan beberapa hasil penelitian yang menunjukkan bahwa periklanan berpengaruh terhadap minat pembelian (Disastra et al., 2019; Mandliya et al., 2020; Martins et al., 2019). Periklanan pada media sosial telah 
mengubah banyak lanskap bisnis (Chu et al., 2019), konsumen saat ini mempunyai kehidupan ganda dimana salah satunya adalah kehidupan pada media sosial, kepemilikan akun sosial media menjelma menjadi ajang aktualisasi diri sekaligus promosi yang berdampak pada berbagai bidang. Iklan yang selama ini sering dipandang sebagai sesuatu yang mengganggu (Gong et al., 2019) bertransformasi menjadi sebuah pesan yang efektif kepada konsumen yaitu menyampaikan mengenai pekan belanja, hari belanja online nasional (harbolnas) dan konsep lain yang sejenis.

Minat beli pelanggan tidak hanya dipengaruhi oleh hal-hal menarik yang ditawarkan oleh Tokopedia, tapi juga dipengaruhi oleh risiko yang dipersepsikan pelanggan. Menurut (Kotler \& Keller, 2016) perceived risk dapat merubah, menunda, bahkan membatalkan keputusan konsumen untuk membeli produk. Hasil penelitian beberapa peneliti sebelumnya menunjukkan bahwa persepsi risiko berpengaruh terhadap minat beli pelanggan (Dabrynin \& Zhang, 2019; Rosillo-Díaz et al., 2019; Tham et al., 2019). Berdasarkan hal tersebut dapat diketahui bahwa perceived risk mampu mempengaruhi minat beli konsumen. Persepsi risiko atau perceived risk adalah ketidakpastian yang dihadapi konsumen ketika mereka tidak dapat memperkirakan konsekuensi atas keputusan pembelian (Schiffman \& Wisenblit, 2015). Kepercayaan dan risiko merupakan predictor yang signifikan dalam kajian behavioural intention (Pelaez et al., 2017). Secara operasional, risiko dapat dimaknai harus dihindari namun makna strategis harus dikelola sedemikian rupa untuk menunjukkan kualitas diri perusahaan dan kualitas dalam mengelola permasalahan (Arora \& Aggarwal, 2018; Pelaez et al., 2017).

Salah satu factor yang berpengaruh terhadap minat pembelian adalah harga (Ghali-Zinoubi \& Toukabri, 2019; Hsu et al., 2017; Wang \& Chen, 2016). Harga sering diindikasikan sebagai indikator nilai yang dihubungkan dengan manfaat (Tjiptono \& Diana, 2020), sekaligus sebagai tantangan dalam bisnis (Hsu et al., 2017). Salah satu kesulitan dalam bisnis adalah kompleksititas dalam memprediksi sensitivitas harga (Hsu et al., 2017; Suryaningsih et al., 2020). Harga adalah pengorbanan konsumen, namun sejauh mana konsumen mau berkorban untuk mendapatkan barang ? masalah yang umum dalam penentuan harga adalah melihat produk, saluran distribusi, serta memperhatikan prestige dari produk. Sensitivitas harga dapat diartikan sebagai tingkat kesadaran dan reaksi yang ditampilkan oleh konsumen ketika menemukan perbedaan harga produk atau jasa. Memahami sensitivitas harga sangat penting untuk mengidentifikasi factor-faktor yang mempengaruhinya. Dalam penelitian ini, sesnsitivitas harga berperan sebagai pemoderasi minat pembelian konsumen. Peran sensitivitas harga harus dimaknai secara luas dan keputusan harga harus dilaksanakan secara konsisten karena harga bukan sekedar mahal dan murah namun bagaimana kepantasan dan dinamika harga berdampak pada minat pembelian konsumen (Cheah et al., 2020; Hsu et al., 2017).

Kebutuhan untuk memahami dan memprediksi dengan lebih baik minat pembelian online khususnya pada produk clothing perlu dilakukan dalam merumuskan strategi bisnis dan strategi pasar yang lebih inovatif. Beberapa ahli melakukan penelitian mengenai factor-faktor yang memengaruhi minat pembelian konsumen baik offline maupun online, namun masih jarang yang melakukan penelitian untuk memprediksi minat pembelian dengan sensitivitas harga sebagai moderasi. Hasil kajian dalam penelitian ini dapat memberikan kontribusi terhadap keberlangsungan usaha dan kemampuan bertahan dalam era saat ini khususnya dalam konteks bisnis digital.

Berdasarkan latar belakang kerangka konseptual dalam penelitian ini tampak pada gambar 1 sebagai berikut.

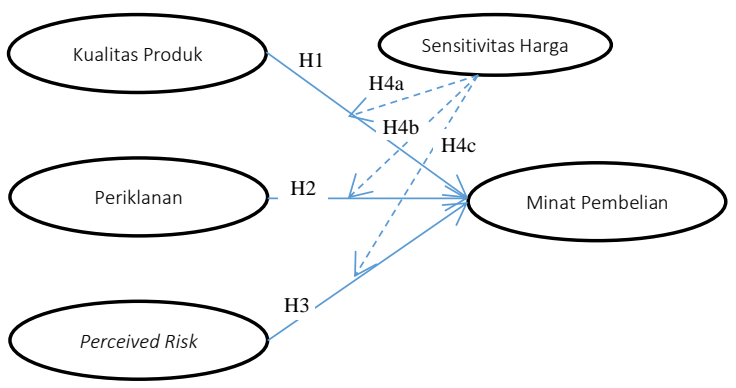

Gambar 1. Kerangka Konseptual

\section{Metode Penelitian}

Penelitian ini dikategorikan sebagai penelitian yang menjelaskan hubungan antar variabel melalui hipotesis yang dirumuskan atau disebut explanatory research untuk mengetahui peran kualitas produk, periklanan dan perceived risk terhadap minat pembelian dengan sensitivitas harga sebagai pemoderasi. Jenis penelitian kuantitatif ini, karena data yang diperoleh nantinya berupa data yang mempunyai karakteristik variabel yang dinyatakan dalam bentuk numerikal menggunakan skala likert dari 1 (sangat tidak setuju) sampai dengan 5 (sangat setuju). Alat pengumpulan data dilakukan dengan menggunakan kuesioner.

Analisis dalam penelitian ini menggunakan model persamaan struktural (SEM-PLS) yang dapat mengoreksi kesalahan pengukuran dengan memasukkan pengaruh interaksi dalam model (Ghozali, 2014) dengan software SMARTPLS 03. SEM-PLS digunakan untuk menguji estimasi dan signifikansi metode Resampling (Bootstrap). Tujuan dari Estimasi SEM-PLS adalah untuk membuat komponen skor terbaik dari variabel endogen, dalam hal ini adalah variabel minat pembelian. Selain itu, SEM-PLS digunakan untuk memprediksi hubungan antara variabel dan indikator melalui inner model yaitu hubungan antara variabel laten dengan model 
luar yaitu hubungan antara indikator dengan variabel latennya (Ghozali, 2014).

Populasi dalam penelitian ini adalah konsumen Tokopedia yang ada di Kota Jember. Karena anggota populasi tidak dapat dipastikan jumlahnya, maka sampel digunakan dalam penelitian ini. Penelitian ini menggunakan teknik purposive sampling sebagai teknik pengambilan sampel. Jumlah sampel yang diambil sebanyak 120 sampel yang didapat dari jumlah indikator penelitian yaitu dua puluh empat (24) indikator dikali lima (5) (Hair Jr et al., 2014). Jumlah sample juga memperhatikan berbagai kriteria termasuk jumlah variabel, indikator dan kecukupan data (Ghozali, 2016).

\section{Hasil dan Pembahasan}

Tabel 1. Hasil Uji Validitas

\begin{tabular}{|c|c|c|c|}
\hline Variabel & $\begin{array}{l}\text { Loading } \\
\text { Factor }\end{array}$ & AVE & Keterangan \\
\hline \multirow[t]{6}{*}{ Kualitas Produk } & 0.897 & \multirow{6}{*}{0.750} & Valid \\
\hline & 0.850 & & Valid \\
\hline & 0.908 & & Valid \\
\hline & 0.945 & & Valid \\
\hline & 0.847 & & Valid \\
\hline & 0.735 & & Valid \\
\hline \multirow[t]{7}{*}{ Periklanan } & 0.886 & \multirow{4}{*}{0.936} & Valid \\
\hline & 0.857 & & Valid \\
\hline & 0.895 & & Valid \\
\hline & 0.905 & & Valid \\
\hline & 0.796 & \multirow{8}{*}{0.672} & Valid \\
\hline & 0.889 & & Valid \\
\hline & 0.822 & & Valid \\
\hline \multirow[t]{5}{*}{ Perceived risk } & 0.846 & & Valid \\
\hline & 0.817 & & Valid \\
\hline & 0.733 & & Valid \\
\hline & 0.826 & & Valid \\
\hline & 0.910 & & Valid \\
\hline \multirow{3}{*}{ Minat Pembelian } & 0.715 & \multirow{3}{*}{0.700} & Valid \\
\hline & 0.852 & & Valid \\
\hline & 0.858 & & Valid \\
\hline \multirow[t]{3}{*}{ Sensitivitas Harga } & 0.884 & \multirow{3}{*}{0.935} & Valid \\
\hline & 0.906 & & Valid \\
\hline & 0.937 & & Valid \\
\hline
\end{tabular}

Sumber : data diolah, 2020

Pada convergent validity tingkat valid atau tidaknya indikator dapat dilihat berdasarkan nilai loading factor. Salah satu kriteria yang digunakan adalah nilai loading factor $\geq 0.70$ (Ghozali, 2014). Tabel 1 menunjukkan bahwa nilai loading factor dari seluruh indikator penelitian bernilai lebih besar dari 0.70 . Demikian juga melihat nilai discriminant validity dengan membandingkan nilai square root of average variance extracted (AVE) setiap konstruk dengan korelasi antar konstruk lainnya dalam model dan direkomendasikan nilai pengukuran harus lebih besar dari 0,50 (Solimun, 2011). diketahui bahwa skor average variance extracted (AVE) seluruh variabel pada penelitian ini > 0,50. Melihat hasil pengujian diatas dapat dikatakan seluruh variabel valid.

Tabel 2. Hasil Uji Composite Reliability

\begin{tabular}{lccc}
\hline Variabel & $\begin{array}{c}\text { Cronbach } \\
\text { Alpha }\end{array}$ & $\begin{array}{c}\text { Composite } \\
\text { Reliability }\end{array}$ & Keterangan \\
\hline Kualitas & 0.932 & 0.947 & Reliable
\end{tabular}

\begin{tabular}{lccc}
\hline \multicolumn{1}{c}{ Variabel } & $\begin{array}{c}\text { Cronbach } \\
\text { Alpha }\end{array}$ & $\begin{array}{c}\text { Composite } \\
\text { Reliability }\end{array}$ & Keterangan \\
\hline Produk & & & \\
Periklanan & 0.909 & 0.936 & Reliable \\
Perceived risk & 0.918 & 0.935 & Reliable \\
Minat & 0.857 & 0.903 & Reliable \\
$\begin{array}{l}\text { Pembelian } \\
\text { Sensitivitas }\end{array}$ & 0.895 & 0.935 & Reliable \\
Harga & & & \\
\hline
\end{tabular}

Sumber : data diolah, 2020

Pada tabel 2 dapat dilihat nilai cronbach alpha dan composite reliability. Nilai cronbach alpha di semua variabel $>0,70$ menandakan bahwa konsistensi jawaban responden dalam satu variabel laten baik atau konsisten. Demikian juga semua variabel pada penelitian ini memiliki skor Composite Reliability > 0,70. Sehingga dapat dikatakan bahwa instrumen penelitian seluruh penelitian adalah reliabel sehingga dapat digunakan untuk uji hipotesis.

Tabel 3. Hasil $\mathrm{R}^{2}$

\begin{tabular}{cc}
\hline Keterangan & Hasil R $^{2}$ \\
\hline Minat Pembelian & 0.808 \\
\hline Sumber : data diolah 2020
\end{tabular}

Sumber : data diolah, 2020

Pada tabel 3 ditunjukkan hasil $\mathrm{R}^{2}$ sebagai salah satu bentuk penilaian inner model. Hasil $\mathrm{R}^{2}$ pada penelitian ini adalah 0.808 atau $80.8 \%$. Hasil $\mathrm{R}^{2}$ sebesar 0.808 masuk dalam kategori kuat dan menunjukkan bahwa variabel kualitas produk, periklanan dan perceived risk mampu menjelaskan sebesar $80,8 \%$ terhadap minat pembelian. Selain $\mathrm{R}^{2}$ pengujian inner model dilakukan dengan melihat nilai predictive relevance $\left(\mathrm{Q}^{2}\right)$. Besaran $\mathrm{Q}^{2}$ memiliki nilai dengan rentang $0<Q^{2}<1$, dimana semakin mendekati 1 berarti model semakin baik (Ghozali, 2014). Uji $Q^{2}$ dilakukan melalui proses blindfolding yang disajikan pada Tabel 4 .

Tabel 4. Hasil $Q^{2}$

\begin{tabular}{cc}
\hline Keterangan & Hasil Q $^{2}$ \\
\hline Minat Pembelian & 0.542 \\
\hline
\end{tabular}

Sumber : data diolah, 2020

Berdasarkan hasil perhitungan nilai predictive relevance untuk variabel minat pembelian sebesar $Q^{2}=0,542$. Hal ini mengindikasikan bahwa model memiliki predictive relevance untuk mengobservasi variabel Minat Pembelian sebesar 54,2\%. Berdasarkan nilai predictive relevance tersebut maka model dapat dikatakan baik atau memiliki nilai prediktif yang baik sehingga dapat digunakan untuk pengujian hipotesis.

Tabel 5. Koefisien Jalur dan Hasil Uji Hipotesis

\begin{tabular}{|c|c|c|c|c|}
\hline Jalur & $\begin{array}{l}\text { Koef } \\
\text { Jalur }\end{array}$ & $\begin{array}{c}\mathrm{t}- \\
\text { statistic }\end{array}$ & $\begin{array}{c}\mathrm{p}- \\
\text { value }\end{array}$ & $\begin{array}{l}\text { Keteran } \\
\text { gan }\end{array}$ \\
\hline Kualitas Produk & 0,740 & 3,351 & 0,001 & Diterima \\
\hline Periklanan & 0,451 & 2,900 & 0,047 & Diterima \\
\hline Perceived risk & 0,358 & 3,816 & 0,000 & Diterima \\
\hline $\begin{array}{l}\text { Kualitas } \\
\text { Produk*Sensitivitas } \\
\text { Harga }\end{array}$ & $-0,385$ & 1,961 & 0,052 & Ditolak \\
\hline $\begin{array}{l}\text { Periklanan*Sentivitas } \\
\text { Harga }\end{array}$ & 0,421 & 2,868 & 0,042 & Diterima \\
\hline $\begin{array}{l}\text { Perceived } \\
\text { risk*Sensitivitas } \\
\text { Harga }\end{array}$ & $-0,031$ & 0,327 & 0,744 & Ditolak \\
\hline
\end{tabular}




\section{Pengaruh kualitas produk terhadap Minat Pembelian}

Hasil penelitian menunjukkan bahwa kualitas produk berpengaruh positif signifikan terhadap minat pembelian produk clothing di Tokopedia, artinya semakin meningkat kualitas produk clothing Tokopedia maka akan semakin meningkat pula minat pembelian pelanggan. Hal tersebut memperkuat teori yang dikemukakan Schiffman \& Wisenblit (2015) yaitu ketika kualitas produk sesuai dengan ekspektasi pelanggan maka kemungkinan besar pelanggan akan melakukan pembelian. Hasil penelitian ini juga sesuai dengan penelitian terdahulu yang menegaskan bahwa kualitas produk berpengaruh terhadap minat pembelian konsumen (Flanagin et al., 2014; Mirabi et al., 2015; Yan et al., 2019).

Ketika kualitas produk sesuai dengan ekspektasi pelanggan maka kemungkinan besar pelanggan berminat untuk melakukan pembelian. Kotler \& Keller (2016) menyampaikan bahwa kualitas produk berperan penting dalam menciptakan costumer value dan costumer satisfaction. Menurut Mirabi et al (2015), kualitas produk adalah seluruh keistimewaan yang ada pada suatu barang untuk memenuhi keinginan pelanggan sehingga memberikan kepuasan atas penggunaan barang tersebut. Kotler \& Keller (2016) menyebutkan ada lima tingkatan dalam mengelola kualitas produk berdasarkan kebutuhan pelanggan, yaitu: core benefit, yaitu benefit atau kebutuhan minimal yang harus dipenuhi perusahaan, contohnya seorang remaja membeli jaket yang tujuannya hanya untuk sekedar dipakai; basic product, setelah mengetahui kebutuhan utama pelanggan maka perusahaan harus mulai mengubah produk core benefit menjadi basic product, yaitu memenuhi standar minimal atribut produk; expected product, selanjutnya perusahaan mulai memahami ekspektasi pelanggan terhadap produk dan mencoba untuk memenuhinya; augmented product, selanjutnya perusahaan mulai mencoba untuk melampaui ekspektasi pelanggan terhadap produk. Hal tersebut bisa dilakukan dengan memberikan harga yang murah, menambahkan fitur atau kelebihan lain pada produk, dan lain-lain ; potential product, selanjutnya produk akan mulai dikenal dan mendapat reputasi yang bagus di mata masyarakat luas. Pada tingkatan ini perusahaan akan dihadapkan oleh tantangan yang lebih berat, alasannya adalah karena ekspektasi pelanggan terhadap produk akan semakin tinggi.

Sensitivitas harga sebagai moderasi pada variabel ini dinyatakan ditolak. Jika ditelisik lebih dalam, perlu dipahami bahwa preferensi konsumen saat ini tidak sekedar pada kualitas saja namun juga pada aspek fashion, kecenderungan untuk bergantiganti mode, tingkat kebosanan sehingga tidak membutuhkan sesuatu yang terkesan awet dan mahal (Watson et al., 2018). Terlebih lagi dalam dunia clothing dan fashion perlu diperhatikan segmen dan target konsumen, karena segmen dan target konsumen akan mempengaruhi bagaimana sensitivitas harga akan direspon oleh segmen dan target tertentu.

\section{Pengaruh Periklanan terhadap Minat Pembelian}

Hasil penelitian menunjukkan bahwa periklanan berpengaruh positif signifikan terhadap minat pembelian produk clothing Tokopedia, artinya semakin baik kinerja Tokopedia dalam melakukan periklanan maka akan semakin meningkat pula minat konsumen untuk melakukan pembelian. Hal tersebut memperkuat teori yang dikemukakan oleh Kotler \& Keller (2016) yaitu iklan memiliki fungsi reminder atau sebagai pengingat yang bertujuan untuk merangsang konsumen agar melakukan pembelian. Hasil penelitian ini juga sesuai dengan penelitian beberapa pakar yang menunjukkan bahwa periklanan berpengaruh terhadap minat pembelian (Chu et al., 2019; Mandliya et al., 2020; Martins et al., 2019).

Tujuan periklanan tergantung bagaimana posisi produk tersebut dipasaran. Membangun kesadaran merek, yaitu menciptakan ingatan tentang produk kedalam benak konsumen. Brand awareness berarti pelanggan mengenali dan mengingat suatu brand atau nama perusahaan ketika mereka hendak membeli suatu produk (Kladou \& Kehagias, 2014). Provide information, yaitu menyediakan informasi mengenai detail usaha seperti jam buka, lokasi usaha, atau sesuatu yang lebih detail seperti spesifikasi produk. Supporting marketing efforts, yaitu bertujuan untuk membantu kegiatan pemasaran yang lain seperti promosi penjualan, membership, dan lain-lain. Encouraging action, yaitu bertujuan untuk meyakinkan para pelanggan sehingga mereka melakukan pembelian dalam jumlah yang lebih banyak, atau dengan kata lain untuk meningkatkan volume penjualan (Shimp \& Andrews, 2013).

Senada dengan pengaruh periklanan terhadap minat pembelian, variabel sensitivitas harga juga mampu memoderasi terhadap minat pembelian. Analisis lebih dalam didapat bahwa konsumen Tokopedia berada pada berbagai segmen namun sebagian besar terpusat pada segmen menengah dan banyak terpengaruh program promosi dan image Tokopedia yaitu jaringan toko daring yang terpercaya, memiliki jam terbang yang tinggi, banyaknya voucher gratis pengiriman, bundling dan lain sebagainya. Periklanan yang masif dan kreatif ditunjang dengan strategi harga yang tepat mampu meningkatkan minat konsumen dalam berbelanja (Ghali-Zinoubi \& Toukabri, 2019; Hsu et al., 2017), khususnya pada hari khusus yang ditetapkan seperti program harbolnas dan program bundling lainnya. 


\section{Pengaruh Perceived risk terhadap Minat Pembelian}

Hasil penelitian menunjukkan bahwa perceived risk berpengaruh positif signifikan terhadap minat pembelian clothing Tokopedia, artinya semakin percaya konsumen terhadap pengelolaan risiko yang dilakukan Tokopedia maka akan semakin meningkat pula minat konsumen untuk melakukan pembelian. Hal ini sesuai dengan hasil penelitian beberapa pakar yang menunjukkan bahwa perceived risk berpengaruh signifikan terhadap minat pembelian (Dabrynin \& Zhang, 2019; Pelaez et al., 2017; Tham et al., 2019).

Mengukur konstruksi risiko yang dirasakan merupakan tantangan. Konstruksi risiko mewakili konstruksi situasional dan pribadi, terutama direpresentasikan sebagai kemungkinan kerugian dan persepsi atau keyakinan tentang konsekuensi yang tidak menguntungkan. Risiko yang dirasakan dapat diukur sebagai gabungan beberapa komponen termasuk risiko keuangan, risiko kinerja, risiko fisik, risiko prokologis serta keseluruhan risiko (Dabrynin \& Zhang, 2019; Pelaez et al., 2017). Tokopedia sebagai penyedia online marketplace tentunya tidak bisa sepenuhnya menghilangkan risiko yang dipersepsikan konsumen. Kerugian yang mungkin terjadi pada online shopping biasanya berupa barang palsu, barang tidak sampai, barang rusak, barang tidak sesuai dengan harganya, pembayaran yang rumit, dan kurangnya informasi terkait barang yang dijual. Berbeda dengan hasil penelian diatas, ternyata sensitivitas harga tidak dapat menjadi moderasi perceived risk terhadap minat pembelian. Hal ini dapat dijelaskan bahwa segmen dan perilaku pembelian menjadi alasan penting dalam pola belanja konsumen.

\section{Kesimpulan}

Penelitian ini membuktikan bahwa kualitas produk, periklanan dan perceived risk merupakan variabel yang berpengaruh signifikan terhadap minat pembelian. Namun sensitivas harga sebagai moderasi hanya mampu memoderasi periklanan terhadap minat pembelian saja. Keseluruhan temuan dalam penelitian ini mengindikasikan bahwa strategi yang tepat perlu memperhatikan segmen dan jenis produk serta nilai utama perusahaan. Memahami perilaku konsumen dan pola belanja konsumen akan menciptakan nilai tambah bagi perusahaan. Walaupun pada kuartal II tahun 2020 transaksi clothing sempat menurun namun mendekati penghujung tahun transaksi mulai meningkat dengan periklanan yang masif khususnya mengenai hari khusus berbelanja dengan aneka voucher yang menguntungkan konsumen.

Model penelitian ini masih memberikan peluang untuk dikembangkan khususnya melibatkan segmen barang mewah serta barang dengan tema tertentu seperti green product, dan lain lain. Selain itu dua hipotesis moderasi yang ditolak dalam penelitian ini masih dimungkinkan untuk dikembangkan dengan berbagai pendekatan khususnya pada bisnis digital.

\section{Referensi}

Arbaini, P., Wahab, Z., \& Widiyanti, M. (2020). Pengaruh Consumer Online Rating Dan Review Terhadap Keputusan Pembelian Pada Pengguna Marketplace Tokopedia. Jurnal Bisnis Dan Manajemen, 7(1), 25-33. https://doi.org/10.26905/jbm.v7i1.3897

Arora, N., \& Aggarwal, A. (2018). The role of perceived benefits in formation of online shopping attitude among women shoppers in India. South Asian Journal of Business Studies, 7(1), 91-110. https://doi.org/10.1108/SAJBS-04-2017-0048

Belarmino, A. M., \& Koh, Y. (2018). How E-WOM motivations vary by hotel review website. International Journal of Contemporary Hospitality Management, 30(8), 2730-2751. https://doi.org/10.1108/IJCHM-02-2017-0055

Calvo-Porral, C., \& Lévy-Mangin, J. P. (2017). Store brands' purchase intention: Examining the role of perceived quality. European Research on Management and Business Economics, 23(2), 90-95. https://doi.org/10.1016/j.iedeen.2016.10.001

Cheah, J. H., Waller, D., Thaichon, P., Ting, H., \& Lim, X. J. (2020). Price image and the sugrophobia effect on luxury retail purchase intention. Journal of Retailing and Consumer Services, $\quad$ 57(April), 102188. https://doi.org/10.1016/j.jretconser.2020.1021 88

Chu, S. C., Kamal, S., \& Kim, Y. (2019). Reexamining of consumers' responses toward social media advertising and purchase intention toward luxury products from 2013 to 2018: A retrospective commentary. Journal of Global Fashion Marketing, 10(1), 81-92. https://doi.org/10.1080/20932685.2018.15500 08

Dabrynin, H., \& Zhang, J. (2019). The Investigation of the Online Customer Experience and Perceived risk on Purchase Intention in China. Journal of Marketing Development and Competitiveness, 13(2), 16-30. https://doi.org/10.33423/jmdc.v13i2.2005

Disastra, G. M., Hanifa, F. H., Wulandari, A., \& Sastika, W. (2019). The Influence of Advertising Value on Advertising Attitude and 
its Impact on Purchase Intention. Advances in Social Science, Education and Humanities Research, 307(SoRes 2018), 426-432. https://doi.org/10.2991/sores-18.2019.98

Flanagin, A. J., Metzger, M. J., Pure, R., Markov, A., \& Hartsell, E. (2014). Mitigating risk in ecommerce transactions: Perceptions of information credibility and the role of usergenerated ratings in product quality and purchase intention. Electronic Commerce Research, 14(1), 1-23. https://doi.org/10.1007/s10660-014-9139-2

Ghali-Zinoubi, Z., \& Toukabri, M. (2019). The antecedents of the consumer purchase intention: Sensitivity to price and involvement in organic product: Moderating role of product regional identity. Trends in Food Science and Technology, 90, 175-179. https://doi.org/10.1016/j.tifs.2019.02.028

Ghozali, I. (2014). Structural Equation Model Metode Alternatif dengan Partial Least Squares (PLS) (4th ed.). Badan Penerbit Universitas Diponegoro.

Ghozali, I. (2016). Aplikasi Analisis Multivariate denganProgram IBM SPSS 23. Badan Penerbit Universitas Diponegoro.

Gong, S., Wang, W., \& Li, Q. (2019). Marketing communication in the digital age : online ads , online WOM and mobile game adoptions. Nankai Business Review International, 10(3), 382-407. https://doi.org/10.1108/NBRI-122018-0073

Hair Jr, J. F., Black, W. C., Babin, B. J., \& Anderson, R. E. (2014). Multivariate Data Analysis (Seventh Ed). Pearson.

Hsu, C. L., Chang, C. Y., \& Yansritakul, C. (2017). Exploring purchase intention of green skincare products using the theory of planned behavior: Testing the moderating effects of country of origin and price sensitivity. Journal of Retailing and Consumer Services, 34(August 2016),

$145-152$. https://doi.org/10.1016/j.jretconser.2016.10.00 6

Kladou, S., \& Kehagias, J. (2014). Assessing destination brand equity: An integrated approach. Journal of Destination Marketing and Management, 3(1), 2-10. https://doi.org/10.1016/j.jdmm.2013.11.002

Kotler, P., \& Keller, K. L. (2016). Marketing Management. In Pearson Education Limited (15e ed., Vol. 15E, Issue 4). Pearson. https://doi.org/10.1080/08911760903022556
Mandliya, A., Varyani, V., Hassan, Y., Akhouri, A., \& Pandey, J. (2020). What influences intention to purchase sustainable products? impact of advertising and materialism. International Journal of Productivity and Performance Management, $\quad 69(8), \quad$ 1647-1669. https://doi.org/10.1108/IJPPM-12-2019-0591

Martins, J., Costa, C., Oliveira, T., Gonçalves, R., \& Branco, F. (2019). How smartphone advertising influences consumers' purchase intention. Journal of Business Research, 94(December 2017), 378-387. https://doi.org/10.1016/j.jbusres.2017.12.047

Mirabi, V., Akbariyeh, H., \& Tahmasebifard, H. (2015). A Study of Factors Affecting on Customers Purchase Intention Case Study : the Agencies of Bono Brand Tile in Tehran. Journal of Multidisciplinary Engineering Science and Technology (JMEST), 2(1), 267273.

Pelaez, A., Chen, C. W., \& Chen, Y. X. (2017). Effects of Perceived risk on Intention to Purchase: A Meta-Analysis. Journal of Computer Information Systems, 59(1), 73-84. https://doi.org/10.1080/08874417.2017.13005 14

Primanto, A. B., ABS, M. K., \& Slamet, A. R. (2018). A Study of The Best Selling Smartphone in The Two Biggest Marketplace in Indonesia. Jurnal Terapan Manajemen Dan Bisnis, 4(1), 17-24. https://doi.org/10.26737/jtmb.v4i1.487

Rosillo-Díaz, E., Blanco-Encomienda, F. J., \& Crespo-Almendros, E. (2019). A cross-cultural analysis of perceived product quality, perceived risk and purchase intention in ecommerce platforms. Journal of Enterprise Information Management, 33(1), 139-160. https://doi.org/10.1108/JEIM-06-2019-0150

Saleem, A., Ghafar, A., Ibrahim, M., Yousuf, M., \& Ahmed, N. (2015). Product Perceived Quality and Purchase Intention withConsumer Satisfaction. Global Journal of Management and Business Research: E Marketing, 15(1), 21-28.

https:/globaljournals.org/GJMBR_Volume15/ 3-Product-Perceived-Quality.pdf

Sasmita, J., \& Mohd Suki, N. (2015). Young consumers' insights on brand equity: Effects of brand association, brand loyalty, brand awareness, and brand image. International Journal of Retail and Distribution Management, 43(3), 276-292. https://doi.org/10.1108/IJRDM-02-2014-0024 
Schiffman, L. G., \& Wisenblit, J. L. (2015). Consumer Behavior Consumer Behavior (11th ed). Pearson.

Shimp, T. A., \& Andrews, J. C. (2013). Integrated Marketing Communications (Ninth Edit). Cengage.

Singhal, D., Jena, S. K., \& Tripathy, S. (2019). Factors influencing the purchase intention of consumers towards remanufactured products: a systematic review and meta-analysis. International Journal of Production Research, 57(23), 7289-7299. https://doi.org/10.1080/00207543.2019.15985 90

Solimun. (2011). Analisis Multivariat Permodelan Struktural Metode Partial Least Square-PLS. CV. Citra Malang.

Suryaningsih, I. B., Nugraha, K. S. W., \& Moelyadi, D. K. (2020). Travel Choice Component: Is The Price Important For Open Trip Tourists ? Jurnal Manajemen, XXIV(02), 266-281. https://doi.org/http://dx.doi.org/10.24912/jm.v $24 \mathrm{i} 2.647$

Tham, K. W., Dastane, O., Johari, Z., \& Ismail, N. B. (2019). Perceived risk factors affecting consumers' online shopping behaviour. Journal of Asian Finance, Economics and
Business, 6(4), 246-260. https://doi.org/10.13106/jafeb.2019.vol6.no4.2 46

Tjiptono, F., \& Diana, A. (2020). Pemasaran. ANDI.

Wang, Y.-H., \& Chen, L.-Y. (2016). An Empirical Study of the Effect of Perceived Price on Purchase Intention Evidence from Low-Cost Carriers. International Journal of Business and Social Science, 7(4), 97-107.

Watson, A., Alexander, B., \& Salavati, L. (2018). The impact of experiential augmented reality applications on fashion purchase intention. International Journal of Retail and Distribution Management. https://doi.org/10.1108/IJRDM-06-2017-0117

Yan, L., Xiaojun, F., Li, J., \& Dong, X. (2019). Extrinsic cues, perceived quality, and purchase intention for private labels: Evidence from the Chinese market. Asia Pacific Journal of Marketing and Logistics, 31(3), 714-727. https://doi.org/10.1108/APJML-08-2017-0176 